年代別にわけると，白壁，拧川らによ机ば55例中15藏 から29歳までの者が殆どで，40歳以降は０です．30代が わずかに 8 人程で，若年者の回腸終末部のリンパ沪胞の 増生は正常であると言われているが，当院の場合は回腸 終末部についても10代 6 名，20代 9 名，30代 9 名，40代 4 名, 50 代 5 名, 60 代 1 名, 70 代 2 名で 29 歳迄が15名で あるのに対し30代以上が21名ではるかに高年者が多いよ うです.

大きさについては，その大半が 1〜3ミり以内で 3.5 ミ リから 7 ミ存含むものが極く少数あり，4之リ以上の なかにはパイエル板の増大と思われるものも含まれてい ます。

形は小円形，楕円形が多了，ながは様々な形の隆起 があり，隆起が高くて增界鮮明なすの，隆起が低りと思 われるあの等がびまん性に散在しています：またポリ一 プとの鑑別に役立つと言われるへそを含む者が 42 名中 33 名に認められました。

この様な微細なリンパ沪胞増殖症の存在を検討する為 には注腸の際の前処犆はもとより，二重造影法及び圧迫 法により鮮明な写真を撮る事が重要であると思われます。

\section{7. 排泄性胆道造影法}

\author{
大晅市民病院 \\ 木村得次 ·金森勇雄 ·馬場健碩
}

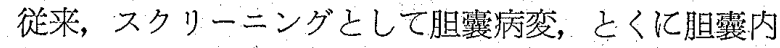
結石の彰断に重点がおかれ，経口法を笑施することが多 かったようである.しかし，胆道は肝，膵，十二指腸等 と密接な関連性をむらており，てれらの臓器の異状が反 映される胆管の造影はルーチン検査として不可欠である また，診断には阻害因子の少ない，情報量の多いX線像 を得るととが最低の条件である，われわれは，春椎，肋 嗗陰影，腸内ガス等との重なりを最小にするた的透視下 で主に経口点滴併用法定実施している，さらに，胆囊の 位置，胆管の走行を立体的に把握し，胆管の各部分を最 良の状態で造影する目的で体位を種々に変操し，撮影を 行なっている。また， 压迫撮影は阻害因子の除去のみな らず，結石の䪭断能を著明に向上させている，乙の方法 により 3 年 6 力月間に 2,700 例の排泄性胆道造影を経験 した.とのうち 1,018 例(37.7\%)飞明らかな異常を諮め た. X線邶断にはそれぞれ限界があるととは充分に理解 して扝くことが前提であるが良し胆道像を得るためには， 撮影するわれわれが読影能力を充分身につけておくとと 大切で，その時々の病態に応じた撮影をするととが必要 である. 今般, 被暴線量の問題がクローズアップされて 〈るが，われわれの方法では透視時間は積算して1分程
度で済み阻害团子による再検査の必要が少なりととから 本法を类施しているととを報告した。

\section{8. 消化器系における血管造影法の実際}

$$
\begin{array}{r}
\text { 目西部浜松医療センタ一放射線科 } \\
\text { ○和田 健・生座本義広 } \\
\text { 野末一司・松原 忍 }
\end{array}
$$

近年，希土類螢光体増感紙の導大を初め高解像度 I. I. などの忘用により被曝線量の軽減化や画筫の向上が計ら れ，その診断に笴与する役割は益々増大してきている。 今回我々は過去 4 年間で消化器系における血管造影検査 を 860 人， 1,780 件施行してきた。その経験をむとにし 次に挙げる事垻について検討した。

1) 希土類螢光体增感紙システムの諸特性

2) 被写体の動き之曝射時間の検討

3）造影部位並びに疾患別による体位，照射野の検討

4) 静眽相における撮影条件の検討

5）診断のポイントを加味したプログラミングの必要 性

6) 薬理効果 (Prostaglandin $\mathrm{E}_{1}$ ) による血管造影法 [結果]

1) 希土類螢光増感紙を使用する場合, 現像温度を指 定温度 $\left(35^{\circ} \mathrm{C}\right)$ より上げ， $37^{\circ} \mathrm{C} \sim 38^{\circ} \mathrm{C}$ 位で処理することも 被曝線量の軽減化につながり，かつFog の少ない良好 なX線写真を得ることができると考える。

2) 動きによるボケは蔵器自体の動きより呼吸による 動きが問題になってくる. 腹腔動脈 2 4 $\mathrm{mm} / \mathrm{sec} の$ 動 きを考えると，曝射時間 $64 \mathrm{msec〜} 80 \mathrm{msec}$ 程度加適当 である、管電圧はヨードの吸収端付近に設定するよう心 掛ける必要がある。

3）動脈分枝の支配領域を充分理解して撮影にあたら なくてはならい.そして照射野を目的にあったように絞 ることあ忘れてはならないう。だし，上腸間膜動脈より accessury hepatic artery が分枝している場合などは横 隔膜まで照射野に入れることす必要になる。

また疾悪によっては正面像だけでなく，斜位，側面像 も当然必要な場合驾ある。

4) 動脈相と静脈相では造影剂の組織内分布の差異に より写真濃度が変化し静脈相での写真濃度が低下する。 このととは造影回数，造影間隔，造影剤注入量及びその 濃度，腎機能等に関係してくる。乙の為静脈相では撮影 途中に10～15\%程度曝射量を多くすること加望京しい.

5）原発性肝癌，転移性肝癌，閉塞性黄疸などの如く， 重篤な肝疾患では静脈相の出現が遅れる。

6）血管拔張剤の為に心拍出量の増加，血流速度の促 